\title{
Modelling of Induction Heating of Steel Work Piece for Forging of Crankshaft
}

\author{
Rasa KANDROTAITÉ JANUTIENÉ *, Darius MAŽEIKA
}

\author{
Department of Production Engineering, Kaunas University of Technology, Studentu st. 56-323, LT-51424, Kaunas, \\ Lithuania
}

crossref http://dx.doi.org/10.5755/j01.ms.24.3.18313

Received 05 June 2017; accepted 06 December 2017

\begin{abstract}
Vanadium microalloyed steel forgings provide high performance and cost effective solutions for automotive components in powertrain and chassis of modern cars and trucks. The majority of these forgings are produced from medium carbon steel with small additions of vanadium, manganese and sulphur to provide precipitation strengthening of the cooled ferrite-pearlite microstructure. This article deals with modelling of induction heating of steel billet prior to forging for automotive applications using COMSOL Multiphysics. The main aim of computer modelling was to evaluate the temperature distribution in billet since precise temperature control is required to prevent process-induced defects such as overheating or insufficient heating. Obtained numerical results for development of induction heating of steel billets have represented eventual increase of effectiveness by reducing of operation time.

Keywords: COMSOL Multiphysics, crankshaft, induction heating, forging.
\end{abstract}

\section{INTRODUCTION}

An induction heating is a common heat treatment technique widely used in automotive manufacturing, castrolling, forging, preheating before rolling, heat treatment, galvanizing, etc. [1-5]. Induction heating is one of the heat treatment technologies where electrically conductive materials (usually metals) are heated in electromagnetic field without any contact between a heating element and a work piece [6].

An induction heating system consists basically of one or several inductors and metallic work pieces to be heated. The inductors are supplied with alternating current which induces eddy currents inside the component being heated due to Faraday's law. In some cases, frequency and power of every inductor can be different, thus, allowing to design required heating mode.

An induction heating used for preheating of work pieces to be forged is efficient, time saving and environmental clean heating process since the heat is generated inside the work piece [5,7]. Metal work pieces are heated up by induction to the required temperatures where proper conditions for plastic deformations are achieved. The rate and efficiency of induction heating depends on physical properties of the work piece. The rate of heating of the work piece is dependent on the frequency and the intensity of the induced current, the specific heat of the material, the magnetic permeability of the material, and the resistance of the material to the flow of current $[8,9]$. Physical properties of material are temperature dependent, and the specific heat, magnetic permeability, and resistivity of metals change with temperature.

However, the induction heating method has some limitations in achieving an even temperature distribution for large size work pieces since the temperature gradient

\footnotetext{
${ }^{*}$ Corresponding author. Tel.: +370-37-300237.

E-mail address: raskand@ktu.lt (R. Kandrotaitė Janutienè)
}

between the surface and the center of the work piece increases significantly as the diameter of it is increased [5].

As the heating for forging requires precise temperature control to prevent the defects such as overheating or underfilling due to insufficient heating, an accurate prediction of the work piece temperature prior to forging is essential. Moreover, induction heating analysis becomes more complex due to the nonlinearity of relative magnetic permeability of ferromagnetic materials such as steel [8].

The steels used in the production of automotive crankshafts are well known in automobile industry as medium carbon micro-alloyed (MCMA) structural steels containing vanadium and increased content of sulphur, that endue higher mechanical properties and machinability, respectively. Vanadium, dissolved in the austenite during heating, precipitates in the form of fine VC particles in proeutectoid ferrite as well as in ferrite lamellae of pearlite on cooling after hot forging, which provides significant increase in strength [10]. Automotive crankshafts of MCMA steels could be produced by forging after induction heating till approximately $1300^{\circ} \mathrm{C}$. Steel heat treatment followed by forging should ensure ferritepearlite microstructure obtaining a good combination of high strength and high toughness mainly through precipitation hardening and grain size refining mainly due to vanadium additive [11]. However, there is some disagreement in literature regarding the effect of dissolved vanadium on transformation behavior of microalloyed steels. It is generally believed that vanadium atoms segregate to austenite grain boundaries rendering them less effective as ferrite nucleation sites. Although many authors suggest that vanadium increases hardenability by preventing grain boundary nucleation, thus suppressing ferrite-pearlite formation, there are opposite opinions, that vanadium actually does not suppress grain boundary reaction and even decreases hardenability [11]. However, high hardenability is not desirable as according requirements of automobile producer, martensitic or bainitic microstructures are not permissible since the 
further machining of the parts with hard spots becomes too complicated and the toughness decreases as well [12]. It was determined that soaking temperature during heating was one of the main factors influencing the transformation of pearlite-ferrite microstructure or much harder bainitic/martensitic constituent $[11,13]$.

The aim of the work was to determine the parameters (induction heating temperature, heating duration) of the induction heating process of the work piece for the further forging operation performed for the production of automotive crankshafts; to evaluate the temperature gradient between the centre and the surface of the work piece depending on heating duration, and to propose development in the mode of induction heating process which could ensure the required microstructure (high temperature austenite and ferrite-pearlite after postforging) of the work piece to be heated and then forged.

\section{EXPERIMENTAL DETAILS}

Standardized chemical composition of forging steel 38MnVS6 is presented in Table 1.

Table 1. Chemical composition of forging steel 38MnVS6 DIN EN 10267 in weight percent [10]

\begin{tabular}{|c|c|c|c|c|c|c|}
\hline $\mathrm{C}$ & $\mathrm{Si}$ & $\mathrm{Mn}$ & $\mathrm{P}$ & $\mathrm{S}$ & $\mathrm{Cr}$ & $\mathrm{V}$ \\
\hline $0.32-$ & $0.15-$ & $1.20-$ & $\leq 0.025$ & $0.045-$ & $\leq 0.30$ & $0.08-$ \\
0.41 & 0.80 & 1.60 & & 0.065 & & 0.20 \\
\hline
\end{tabular}

Data received from a producer of crankshafts containing parameters of the induction heating process and the work pieces, and used for the further calculations is presented in Table 2.

An inductor "Newelco" used in heating process was composed of four segments with the same length. Each segment had different heating power, i.e. the first three segments were used for heating up the billet until the required temperature and the last one - for minimizing of temperature gradient between surface and centre of the billet. The total length of the inductor was 6 meters. The gap between segments was very small, therefore, designing 3D model (Fig. 1) in Solidworks environment the gap was eliminated. The inductor was designed as an entire copper tube with cooling by water of $20-30{ }^{\circ} \mathrm{C}$.

The software used for induction heating simulation was COMSOL Multiphysics version 5.2.

In our model situation based on real engineering application, the work pieces are constantly moving through the coil tunnel with a certain velocity, which means, approximately every $24-28$ seconds the properly heated work piece drops out. To simplify a calculation and to reduce solving time, there was considered a moving bar instead of number of separate involving work pieces. The desired forming temperature of steel work piece in the end of inductor should be in the range of $1250-1290{ }^{\circ} \mathrm{C}$. Heating duration and moving velocity of the work piece were calculated for every drop out time (Table 3).

Material properties of heated steel work pieces are non-linear temperature dependent, which means they are changing during heating cycle. Material properties used for numerical simulation in COMSOL Multiphysics environment are listed in Table 4. Relative magnetic permeability of steel was chosen $\mu=1$ since steel becomes nonmagnetic above Curie temperature $\left(770^{\circ} \mathrm{C}\right)[2,4,7,9]$.

Table 2. Operating parameters about work pieces and induction heating process given by a producer of crankshafts

\begin{tabular}{|l|c|c|}
\hline \multicolumn{1}{|c|}{ Parameter } & Unit & Value \\
\hline Diameter of work piece & $\mathrm{mm}$ & $78 ; 88$ \\
\hline Length of work piece & $\mathrm{mm}$ & 407 \\
\hline Total length of inductor & $\mathrm{m}$ & $4 \times 1.5$ \\
\hline Material of inductor tube & - & copper \\
\hline $\begin{array}{l}\text { Dimensions of inductor's tube } \\
\text { cross-section (height and width) }\end{array}$ & $\mathrm{mm}$ & $25 \times 13$ \\
\hline $\begin{array}{l}\text { Wall thickness of inductor's } \\
\text { tube }\end{array}$ & $\mathrm{mm}$ & 1.5 \\
\hline Number of turns in one coil & - & 39 \\
\hline Initial diameter of coil & $\mathrm{mm}$ & 150 \\
\hline $\begin{array}{l}\text { Frequency (same in all } \\
\text { segments of inductor) }\end{array}$ & $\mathrm{Hz}$ & 1000 \\
\hline $\begin{array}{l}\text { Current: } \\
\text { 1 segment }\end{array}$ & & $1400-1600$ \\
2 segment & $\mathrm{A}$ & 1600 \\
3 segment & & 1600 \\
4 segment & & 1300 \\
\hline $\begin{array}{l}\text { Power: } \\
1 \text { segment }\end{array}$ & $\mathrm{kW}$ & 250 \\
2 segment & & 140 \\
3 segment & $\mathrm{s}$ & 606 \\
4 segment & ${ }^{\circ} \mathrm{C}$ & $20-30$ \\
\hline $\begin{array}{l}\text { Temperature of water of tube } \\
\text { cooling }\end{array}$ & & $28 ; 26 ; 27 ;$ \\
\hline $\begin{array}{l}\text { Time interval between every } \\
\text { drop out of work pieces after } \\
\text { induction heating }\end{array}$ & & \\
\hline
\end{tabular}

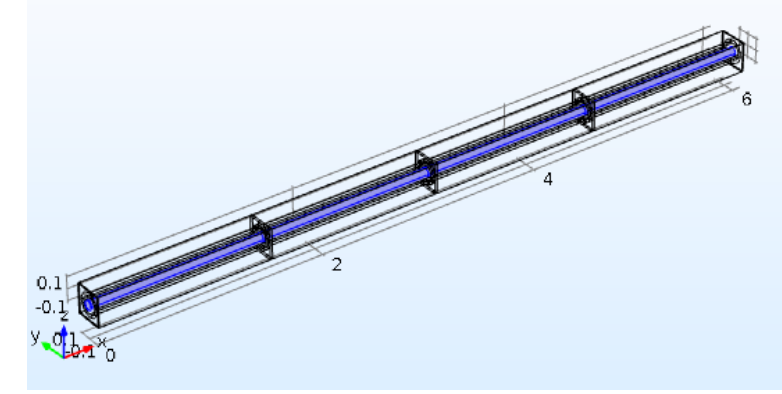

Fig. 1. 3D calculating model. Units of measurement - meters

Fine free tetrahedral mesh was applied for the work piece because of proper calculation of electromagnetic phenomena (Fig. 2).

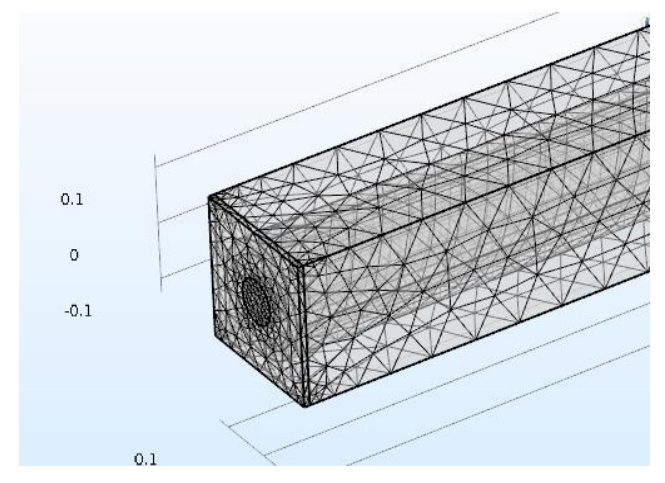

Fig. 2. Finite element model 
Table 3. Heating duration and moving velocity of work piece of 407 mm length

\begin{tabular}{|c|c|c|c|}
\hline $\begin{array}{c}\text { Drop out } \\
\text { time, } \mathrm{s}\end{array}$ & $\begin{array}{c}\text { Heating } \\
\text { duration, } \mathrm{s}\end{array}$ & $\begin{array}{c}\text { Length of } \\
\text { inductor, } \mathrm{m}\end{array}$ & $\begin{array}{c}\text { Moving } \\
\text { velocity, } \mathrm{cm} / \mathrm{s}\end{array}$ \\
\hline 24 & 353.81 & 6 & 1.70 \\
\hline 25 & 368.55 & 6 & 1.63 \\
\hline 26 & 383.29 & 6 & 1.57 \\
\hline 27 & 398.03 & 6 & 1.51 \\
\hline 28 & 412.78 & 6 & 1.45 \\
\hline
\end{tabular}

Table 4. Material properties used in numerical calculation

\begin{tabular}{|l|c|c|c|}
\hline \multicolumn{1}{|c|}{ Parameter } & Name & Unit & Value \\
\hline Relative permeability & $\mu$ & - & 1 \\
\hline Electrical conductivity & $\sigma$ & $\mathrm{S} / \mathrm{m}$ & $6.21 \times 10^{6}$ \\
\hline $\begin{array}{l}\text { Heat capacity at } \\
\text { constant pressure }\end{array}$ & $C p$ & $\mathrm{~J} / \mathrm{kg} \cdot \mathrm{K})$ & 440 \\
\hline Relative permittivity & $\varepsilon$ & - & 1 \\
\hline Density & $\rho$ & $\mathrm{kg} / \mathrm{m}^{3}$ & 7800 \\
\hline Thermal conductivity & $k$ & $\mathrm{~W} /\left(\mathrm{m}^{\prime} \mathrm{K}\right)$ & 14 \\
\hline $\begin{array}{l}\text { Coefficient of thermal } \\
\text { expansion }\end{array}$ & $\alpha$ & $1 / \mathrm{K}$ & $1.1 \times 10^{-5}$ \\
\hline Young's modulus & $E$ & $\mathrm{~Pa}$ & $2.1 \times 10^{11}$ \\
\hline Poisson's ratio & $v$ & - & 0.28 \\
\hline
\end{tabular}

\section{RESULTS AND DISCUSSION}

Soaking temperature has a high influence on the further formation of the type of microstructure. Here, the vanadium carbides play an important role since they act as nucleation sites during transformation. The investigation of the influence of heating temperature and vanadium content on transformation behavior and mechanical properties of medium carbon steels showed that vanadium in solid solution promotes the formation of bainite following low heating temperatures $\left(950-1150{ }^{\circ} \mathrm{C}\right)$, whereas for high heating temperatures $\left(1250-1300{ }^{\circ} \mathrm{C}\right)$ ferrite (ferritepearlite) becomes dominant structure [11]. Some scientists call this type of ferrite as acicular ferrite since it has appearance of needle-shaped microstructure, e.g. Widmanstatten ferrite looks like $[11,14,15]$. Temperature influence could be explained by different nucleation sites for bainite or ferrite formation. It is accepted that the nucleation of randomly oriented acicular ferrite takes place inside the austenite grains at certain nonmetallic inclusions and/or precipitates, while parallel bainitic sheaves nucleate at the austenite grain boundaries [11]. Lower heating temperatures cause less dissolution of vanadium carbides as well as the content of nucleation sites required for the formation of the bainitic sheaves. It is determined that VC particles dissolves into austenite in the range of $950-1050{ }^{\circ} \mathrm{C}$ temperature $[13,16-18]$, therefore, for decreasing the possibility of bainitic particles nucleation, the temperature of the core of billet after heating should reach sufficiently higher temperature ensuring fully dissolved vanadium carbides. The microstructure areas containing bainitic sheaves of the specimen cut from the crankshaft are presented in Fig. 3. The examination of microstructure of crankshaft was performed in Customer laboratory and the results were submitted to crankshafts producer [19].

Temperature of the surface and the core of the work piece was calculated changing moving velocity and diameter of the work piece. Initial temperature of heated steel bar was set $20^{\circ} \mathrm{C}$ and expected forming temperature in the end of inductor was set $1260{ }^{\circ} \mathrm{C}$. The timedependent-temperature distribution in work pieces through whole inductor length gives a sufficiently accurate view on induced heat to the surface of work piece and to the core as well (Fig. 4).

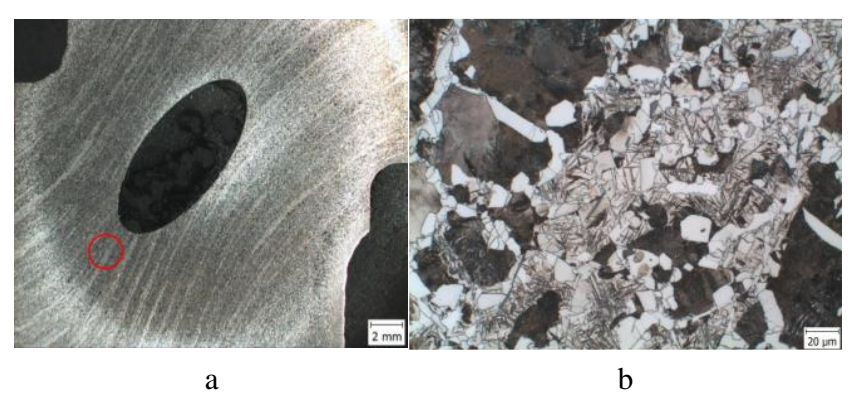

Fig. 3. Examination of randomly chosen crankshaft for the prevention of bainitic microstructure: a-red circle indicates the place of microstructure for microscopic analysis; $b$-needle-shaped sheaves of bainite located in bright areas of microstructure. CIE LT Forge data [19]

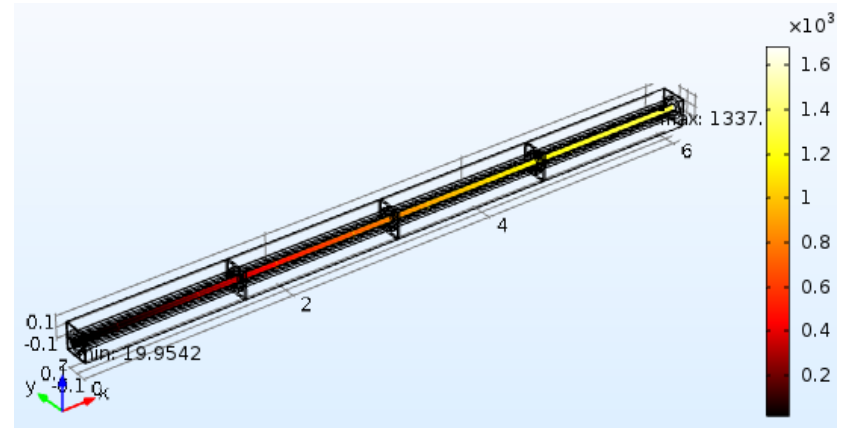

Fig. 4. Time-dependent-temperature distribution through all length of work piece

Solved temperature-to-time profile of the surface and the core of the work piece with the diameter of $88 \mathrm{~mm}$ symmetrically placed and heated in the whole length of the four-segment inductor is shown in Fig. 5. Transformation temperature $A_{c 3}$ of micro alloyed steel $38 \mathrm{MnSV6}$, above which the microstructure of heated steel fully turns to austenite, is determined to be $810^{\circ} \mathrm{C}$ [20]. This value is marked by the line in every figure in Fig. 5. Simulation of induction heating showed that the work pieces of diameter of $88 \mathrm{~mm}$ and $78 \mathrm{~mm}$ were heated $250 \mathrm{~s}$ and $225 \mathrm{~s}$, respectively, in order to reach $A_{c 3}$ temperature.

For the work piece with the diameter of $90 \mathrm{~mm}$ when the frequency of the inductor is $1000 \mathrm{~Hz}$, recommended heating time is 4.6 minutes, i. e. 276 seconds, hence temperature difference between the surface and the core should not increase $100-150{ }^{\circ} \mathrm{C}[21,22]$. This condition was accomplished since the total heating duration was calculated to be more than $300 \mathrm{~s}$ for every drop out time (Table 5).

Similarly, there was determined, that when the steel AISI 1045 (carbon content $\sim 0.45 \%$ ) was heated with the rate of $1{ }^{\circ} \mathrm{C} / \mathrm{s}$, from $A_{\mathrm{c} 1}$ to $99 \%$ of austenitic phase was obtained after approximately 40 seconds and just 1 second was required for this transformation when heating rate was 
up to $100{ }^{\circ} \mathrm{C} / \mathrm{s}$ [23]. However, this type of steel heated by the induction heating till the lower temperature than $900{ }^{\circ} \mathrm{C}$ contained retained ferrite and pearlite [24]. The temperature $A_{c 3}$ for this steel is $755^{\circ} \mathrm{C}[21,22]$ therefore the required overheat was determined to be $145^{\circ} \mathrm{C}$.

Agreeably to this data found and knowing that the steel 38MnVS6 consists of pearlite and ferrite and needs to reach the temperature $A_{c 3}$ for full austenitic microstructure, the overheat range from $A_{c 3}$ to the temperature of heating end was estimated. This overheat value was set for the center line of the work piece since the very core of the work piece was affected just by the convectional heating.
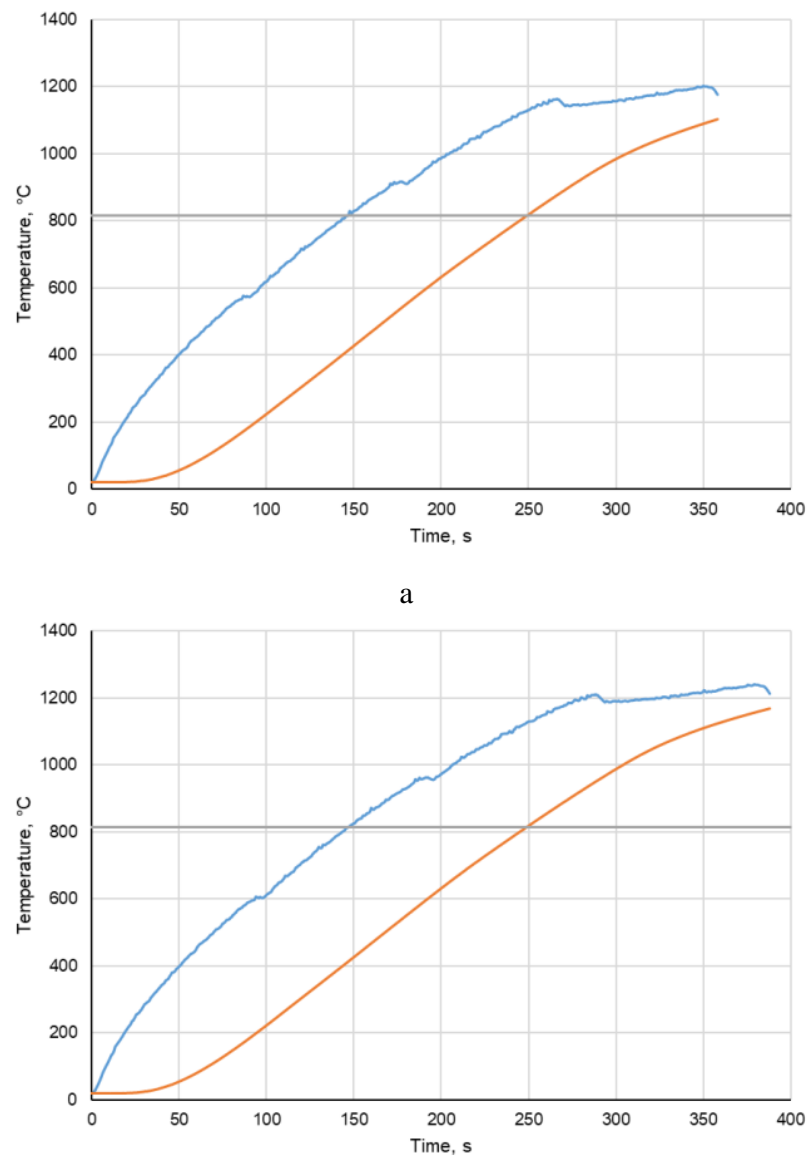

$\mathrm{c}$
Data of overheating parameters of the work piece core was calculated for each diameter of the steel bar and every drop out time. The values of calculation are presented in Table 5.

Calculated results for work piece of $88 \mathrm{~mm}$ diameter show that temperature gradient between work piece surface and centre at the shortest drop out interval is $78^{\circ} \mathrm{C}$; and for work piece of $78 \mathrm{~mm}$ is $28^{\circ} \mathrm{C}$, respectively.

This gradient in both cases can be increased, because recommended temperature gradient is $100^{\circ} \mathrm{C}$ for both diameters $[21,22]$.

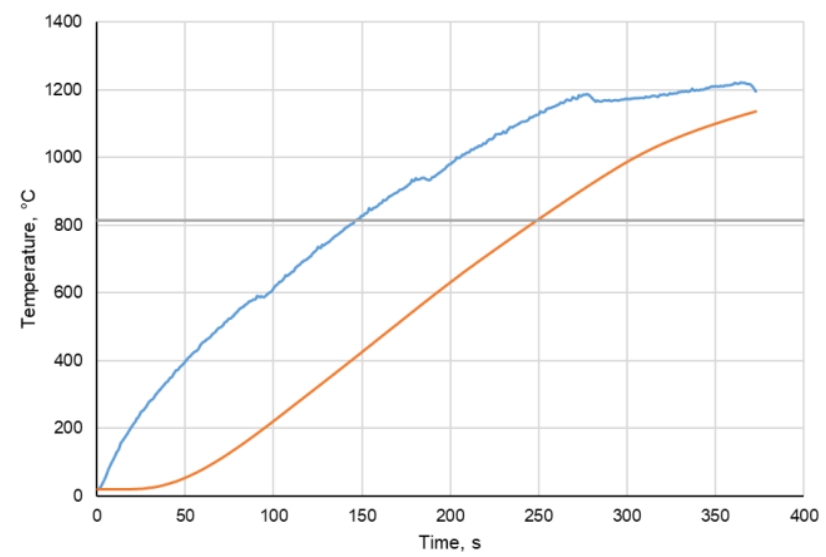

b

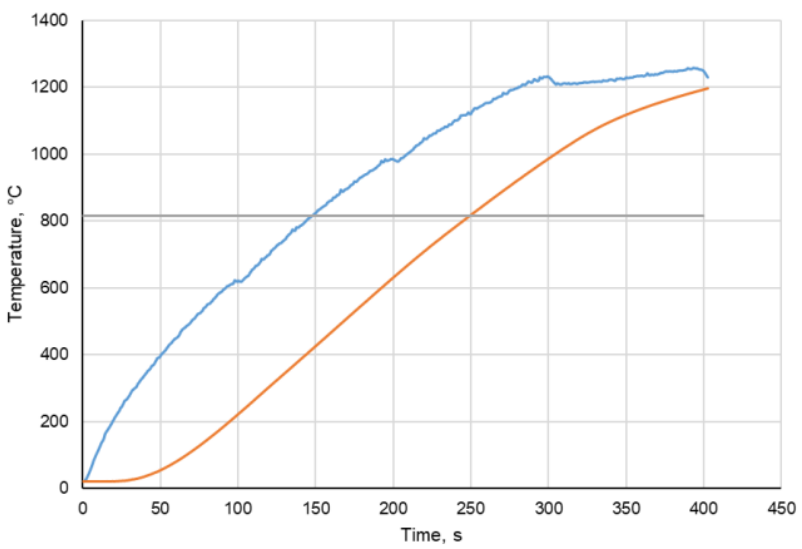

d

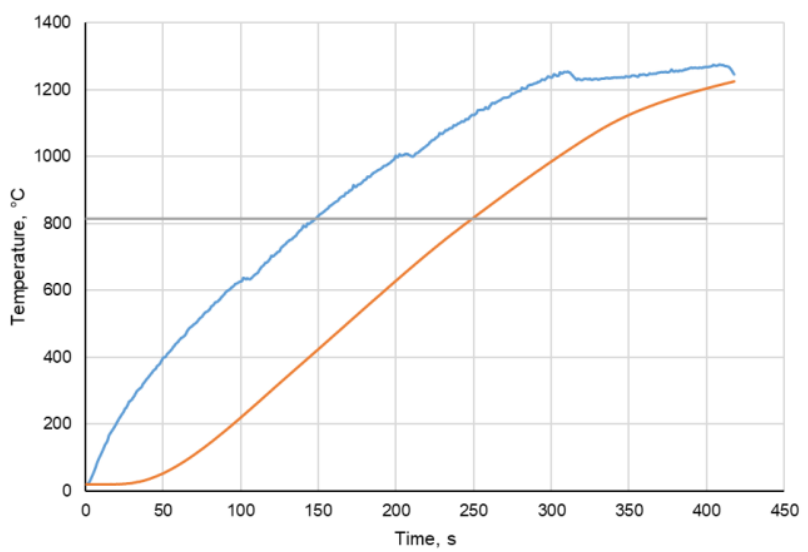

e

Fig. 5. Simulated temperature curves of surface (blue) and centre (red) at different drop out time of the billet with $88 \mathrm{~mm}$ diameter: $\mathrm{a}-24 \mathrm{~s} ; \mathrm{b}-25 \mathrm{~s} ; \mathrm{c}-26 \mathrm{~s} ; \mathrm{d}-27 \mathrm{~s} ; \mathrm{e}-28 \mathrm{~s}$ 
Table 5. Calculated parameters of overheating of work piece centre line

\begin{tabular}{|c|c|c|c|c|c|}
\hline \multicolumn{6}{|c|}{ Diameter of work piece $88 \mathrm{~mm}$} \\
\hline $\begin{array}{l}\text { Drop out } \\
\text { interval, } \mathrm{s}\end{array}$ & $\begin{array}{c}\text { Total } \\
\text { heating } \\
\text { duration, } \mathrm{s}\end{array}$ & $\begin{array}{c}\text { Duration of heating of } \\
\text { work piece centre above } \\
A_{c 3}, \mathrm{~s}\end{array}$ & $\begin{array}{c}\text { Temperature } T_{c} \text { of work } \\
\text { piece centre at the end } \\
\text { of heating, }{ }^{\circ} \mathrm{C}\end{array}$ & $\begin{array}{c}\text { Overheating gradient of } \\
\text { work piece centre } \\
\Delta T=T_{\mathrm{c}}-A_{c 3},{ }^{\circ} \mathrm{C}\end{array}$ & $\begin{array}{l}\text { Temperature gradient } \\
\text { between surface and } \\
\text { centre of work piece, }{ }^{\circ} \mathrm{C}\end{array}$ \\
\hline 24 & 358 & 108 & 1104 & 294 & 78 \\
\hline 25 & 373 & 123 & 1137 & 327 & 68 \\
\hline 26 & 388 & 138 & 1169 & 359 & 57 \\
\hline 27 & 403 & 153 & 1198 & 388 & 48 \\
\hline 28 & 418 & 168 & 1225 & 415 & 39 \\
\hline \multicolumn{6}{|c|}{ Diameter of work piece $78 \mathrm{~mm}$} \\
\hline $\begin{array}{l}\text { Drop out } \\
\text { interval, } \mathrm{s}\end{array}$ & $\begin{array}{c}\text { Total } \\
\text { heating } \\
\text { duration, } \mathrm{s} \\
\end{array}$ & $\begin{array}{l}\text { Duration of heating of } \\
\text { work piece centre above } \\
\qquad A_{c 3}, \mathrm{~s}\end{array}$ & $\begin{array}{c}\text { Temperature } T_{c} \text { of work } \\
\text { piece centre at the end } \\
\text { of heating, }{ }^{\circ} \mathrm{C}\end{array}$ & $\begin{array}{c}\text { Overheating gradient of } \\
\text { work piece centre } \\
\Delta T=T_{\mathrm{c}}-A_{c 3},{ }^{\circ} \mathrm{C} \\
\end{array}$ & $\begin{array}{c}\text { Temperature gradient } \\
\text { between surface and } \\
\text { centre of work piece, }{ }^{\circ} \mathrm{C}\end{array}$ \\
\hline 24 & 358 & 133 & 1176 & 366 & 28 \\
\hline 25 & 373 & 148 & 1206 & 396 & 21 \\
\hline 26 & 388 & 163 & 1234 & 424 & 14 \\
\hline 27 & 403 & 178 & 1259 & 449 & 8 \\
\hline 28 & 418 & 193 & 1283 & 473 & 2 \\
\hline
\end{tabular}

In this case in order to save production costs, the drop out interval can be minimized to $24 \mathrm{~s}$ or less. However, induction heating machine at manufacturing company is too powerful for this diameter work pieces and maximum conveyor speed is too low. Our recommendation is to minimize drop out coefficient more than $24 \mathrm{~s}$ for $88 \mathrm{~mm}$ work pieces, and much more for $78 \mathrm{~mm}$ work pieces.

\section{CONCLUSIONS}

Simulation of the induction heating of the work piece made of 38MnVS6 steel in four-segment inductor revealed that varying the drop out interval from $24 \mathrm{~s}$ to $28 \mathrm{~s}$ the total heating duration is sufficient in all cases:

1. Calculated results showed that the temperature of the centre part of billet has reached more than $1100{ }^{\circ} \mathrm{C}$ thus ensuring the full dissolution of vanadium carbides and allowing to prevent the formation of bainitic sheaves;

2. Overheating gradient above $A_{c 3}$ temperature of the work piece centre is more than $200{ }^{\circ} \mathrm{C}$ for both diameters of the work piece and every drop out interval;

3. Temperature gradient between the surface and centre of the work piece is less than recommended $100{ }^{\circ} \mathrm{C}$ for both diameters of the work piece and every drop out interval;

4. In order to save production costs, the drop out interval can be minimized to $24 \mathrm{~s}$.

\section{Acknowledgments} Forge.

The work was performed in cooperation with CIE LT

\section{REFERENCES}

1. Mei, R., Li, Ch., Liu, X., Li, B., Han, B. Modeling of Slab Induction Heating in Hot Rolling by FEM Engineering 3 2011: pp. $364-370$.

https://doi.org/10.4236/eng.2011.34041

2. Kapusta, J., Camber, J., Hulko, G. Modeling of Induction Heating of Steel Billets for DPS Control Design Purposes
Proceeding of the 2012 COMSOL Conference in Bangalore 2012: pp. $1-7$.

3. Nalawade, R. S., Puranik, A. J., Balachandran, G., Mahadik, K. N., Balasubramanian, V. Simulation of Hot Rolling Deformation at Intermediate Passes and its Industrial Validity International Journal of Mechanical Sciences 77 2013: pp. $8-16$. https://doi.org/10.1016/j.ijmecsci.2013.09.017

4. Morandi, A., Fabbri, M. In-depth Induction Heating of Large Steel Slabs by means of DC Saturating Field produced by SC Coils IEEE/CSC \& ESAS Superconductivity News Forum (global edition) 2016: pp.1-7.

5. Song, M. Ch., Moon, Y. H. Coupled Electromagnetic and Thermal Analysis of Induction Heating for the Forging of Marine Crankshafts Applied Thermal Engineering 98 2016: pp. $98-109$. https://doi.org/10.1016/j.applthermaleng.2015.11.129

6. Djellabi, K., Latreche, M. E. H. Induction Heating Process Design Using Comsol Multiphysics Software Version 4.2a International Journal of Electric 8 (1) 2014: pp. $72-75$.

7. Istardi, D., Triwinarko, A. Induction Heating Process Design Using COMSOL Multiphysics Software Telkomnika 9 (2) 2011: pp. 327-334.

8. Haimbough, R. E. Practical Induction Heat Treating ASM International 2001: p. 332.

9. Rudnev, V., Fett, G. A., Griebel, A., Tartaglia, J. ASM Handbook, Volume 4C: Induction Heating and Heat Treatment ASM International 2014: p. 820.

10. Li, Y., Milbourn, D. J. Vanadium Microalloyed Forging Steel Proceeding of The 2nd International Symposium on Automobile Steel, Anshan, China 2013: pp. 47-54.

11. Hui, W., Zhang, Y., Shao, Ch., Chen, S., Zhao, X., Dong, H. Effect of Cooling Rate and Vanadium Content on the Microstructure and Hardness of Medium Carbon Forging Steel Journal of Materials Science \& Technology 32 2016: pp. 545-51. https://doi.org/10.1016/j.jmst.2016.01.006

12. EN10267 Ferritic-pearlitic steels for precipitation hardening from hot-working temperatures. 1998.

13. Miyamoto, G., Hori, R., Poorganji, B., Furuhara, T. Interphase Precipitation of VC and Resultant Hardening in V-added Medium Carbon Steels ISIJ International 51 (10) 2011: pp. $1733-1739$. 
https://doi.org/10.2355/isijinternational.51.1733

14. Babu, S.S., Bhadeshia, H.K.D.H. Mechanism of the Transition from Bainite to Acicular Ferrite Materials Transactions JIM 32 (8) 1991: pp. 679-688. https://doi.org/10.2320/matertrans1989.32.679

15. Bhadeshia, H.K.D.H., Honeycombe, $\mathbf{R}$. Microstructure and Properties, Third edition 2006: p. 357.

16. Glišić, D., Radović, N., Koprivica, A., Fadel, A., Drobnjak, D. Influence of Reheating Temperature and Vanadium Content on Transformation Behavior and Mechanical Properties of Medium Carbon Forging Steels ISIJ International 50 (4) 2010: pp. 601-606. https://doi.org/10.2355/isijinternational.50.601

17. Popov, V.V., Gol'dshtein, M.I. Dissolution of Carbides and Nitrides during Austenitizing of Steel Translated from Metallovedenie i Termicheskaya Obrabotka Metallov 7 1991: pp. 5-6.

18. Kaynar, A., Gündüz, S., Türkmen, M. Investigation on the Behaviour of Medium Carbon and Vanadium Microalloyed
Steels By Hot Forging Test Materials and Design 2013: pp. 819-825.

https://doi.org/10.1016/j.matdes.2013.04.102

19. Customer Metalurgical Protokol 06052/01-2014: p. 3.

20. Bo, Zh., Yong, Sh., Li, T., Hong-Xin, Y. Research on a New Process of the Non-quenched and Tempered Steel with High Strength and High Toughness Physics Procedia 50 2013: pp. $25-31$.

https://doi.org/10.1016/j.phpro.2013.11.006

21. Petrov, P. A., Krutina, E. V., Kalpin, J. G. Heating and heating equipment for forging production MAMI, Moscow 2010: p. 110. (in Russian).

22. Rudnev, V., Loveless, D., Cook, R., Black, M. Handbook of Induction Heating Marcel Dekker, Inc. 2003: p. 797.

23. Yang, B. J., Hattiangadi, W. Z. Li, Zhou, G. F., McGreevy, T.E. Simulation of Steel Microstructure Evolution during Induction Heating Materials Science and Engineering A 527 2010: 2978-2984. https://doi.org/10.1016/j.msea.2010.01.038

24. Mansurov, A. Technology of Hot Forging Machines Engineering 1970: p. 414. (in Russian). 